\title{
REPRESENTASI CALON PRESIDEN DAN CALON WAKIL PRESIDEN DALAM IKLAN POLITIK LUAR RUANG PARTAI DEMOKRAT
}

\author{
Tri Sulityaningtyas \\ Institut Teknologi Bandung \\ trining_ism@yahoo.co.id
}

\begin{abstract}
Abstrak
Hiruk pikuk pemilu yang baru berlangsung membawa beberapa hal yang menarik. Salah satu hal yang layak untuk diteliti adalah iklan politik. Iklan politik merupakan sarana utama aktivitas politik dalam mendulang dukungan pemilih. Para tokoh politik berlomba-lomba menggunakan iklan sebagai media mencitrakan diri sebagai sosok pemimpin bangsa yang ideal sehingga laik untuk dipilih dalam pemilu. Di dalam iklan politik, bahasa menjadi media yang ampuh untuk menanamkan ideologi, mendapatkan, serta mempertahankan kekuasaan. Berbagai piranti kebahasaan dimanfaatkan untuk meraih simpati, menarik perhatian, membentuk persepsi, mengendalikan pikiran, perilaku, serta nilai yang dianut khalayak. Tulisan ini bertujuan untuk mengkaji bagaimana cara capres-cawapres dari partai Demokrat merepresentasikan dirinya dalam bahasa iklan politik pemilu di Indonesia. Selain itu, akan dikaji pula penggunaan manipulasi bahasa iklan demi meraih berbagai kepentingan politik. Dalam tulisan ini juga akan dibahas pola relasi antara capres-cawapres dan konstituen pemilih. Berdasarkan analisis, diperoleh hasil bahwa kandidat capres dan cawapres partai Demokrat direpresentasikan sebagai sosok yang bersih, selalu berjuang untuk rakyat, merupakan presiden pilihan, berkomitmen untuk membangun pemerintahan bersih, dan berkomitmen untuk membangun rakyat Indonesia.
\end{abstract}

Kata kunci : representasi, relasi, dan manipulasi

\section{Abstract}

The hurly-burly of the election that has just happened brings out several interesting things. One of the things suitable to be researched is political advertisements. Political advertisements are the main tool of political 
activities in gaining the voters' votes. The political figures are contesting to use advertisements as the media to represent themselves as an ideal nation leader so that they are suitable to be voted in the election. In political advertisements, language becomes the effective media to implant ideology, gaining and maintaining power. Various language tools are benefitted to gain sympathy, attract attention, form perception, control mind, behavior, and values that the society has. This writing aims to examine how the president and vice president candidates from Demokrat party represent themselves in the election political advertisements' language in Indonesia. Besides, it will also examine the use of advertisements' language manipulation to gain various political interests. In this writing, it will also discuss relation pattern between president and vice president candidates and the voters' constituent. Based on the analysis, it is gained a result that the president and vice president candidates of Demokrat party are represented as the figures that are clean, always fight for people, chosen president, commit to build clean government, and commit to prosper Indonesians.

Keywords: representation, relation, and manipulation

\section{Pendahuluan}

Bahasa memiliki arti yang sangat penting dalam dunia politik. Bahasa menjadi media ampuh untuk menanamkan ideologi, mendapatkan, serta mempertahankan kekuasaan. Berbagai piranti kebahasaan dimanfaatkan untuk meraih simpati, menarik perhatian, membangun persepsi terhadap suatu masalah, mengendalikan pikiran, perilaku, serta nilai yang dianut khalayak. Sejak era reformasi, bangsa Indonesia telah dua kali melaksanakan pemilu, yaitu tahun 2004 dan 2009. Perubahan sistem pemilihan yang dilakukan secara langsung oleh rakyat dan berbasis pada perolehan suara terbanyak mengakibatkan setiap partai politik selalu berusaha menemukan cara-cara paling efektif untuk mendapatkan sebanyak-banyaknya massa pemilih. Salah satu cara mendapatkan massa pemilih tersebut adalah melalui pesan-pesan politik dari para kandidat.

Hal tersebut bertujuan untuk merebut hati dan simpati khalayak para calon pemilih. Melalui iklan politik para politisi berlomba-lomba menampilkan citra positif dirinya. Dengan demikian, iklan politik kini lebih berfungsi sebagai arena pencitraan. Para tokoh politik mencitrakan bahwa diri mereka adalah sosok pemimpin bangsa yang ideal sehingga laik untuk dipilih dalam pemilu. Iklan politik mengemas tokoh politik dengan strategi tertentu supaya mereka dapat dipandang pantas menjadi pemimpin bangsa.

Melalui iklan politik, partai, para caleg (calon legislatif), capres (calon presiden), atau calon pemimpin daerah ingin cepat dikenal oleh pemilih. Mereka meyakini bahwa iklan yang terus-menerus ditampilkan memiliki daya magis untuk memperkenalkan diri dan merayu calon pemilih secara instan. Adanya pepatah "tak kenal maka tak sayang" menurut Jazeri (2009) rupanya menjadi landasan berpikir mengapa partai, para caleg, capres, atau calon kepala daerah dalam mengiklankan diri di berbagai media. Belum puas dengan itu, mereka memasang baliho, poster, atau spanduk. Melalui iklan tersebut, mereka menebar pesan visual dan verbal yang berupa janji-janji seolah masalah besar bangsa ini dapat terselesaikan dengan cepat jika mereka terpilih.

Ranah, Volume 3, Nomor 1, Juli 2014 | 61 
Di Indonesia, iklan politik relatif merupakan sesuatu yang baru. Iklan politik di Indonesia muncul pertama kali menjelang pemilu 1999 ketika Indonesia kembali mengadopsi sistem multipartai. Perubahan sistem pemilihan yang ditetapkan melalui putusan Mahkamah Konstitusi yang berbasis pada perolehan suara di dalam pemilihan langsung telah membuat para kontestan mengubah strategi. Sistem perolehan suara terbanyak, membawa atmosfer kompetisi yang semakin ketat. Tidak hanya dengan partai lawan, tetapi juga dengan rekan separtai. Kekuatan figur menjadi sangat penting. Salah satu cara memperkenalkan figur tersebut melalui berbagai atribut kampanye yang dianggap simbol representasi calon.

Menjelang pemilu, muatan iklan politik semakin beragam, ada caleg yang memosisikan diri sebagai oposan, ada yang menonjolkan keberhasilan selama memerintah, ada yang memaparkan visi-misi, memunculkan slogan-slogan, akronim nama, hingga saling serang antarkandidat. Bahasa merupakan alat yang digunakan untuk berbagai kepentingan tersebut. Pada beberapa iklan, bahasa yang digunakan tidak begitu jelas ditujukan kepada kelas sosial mana, mereka cenderung menggunakan pilihan kata yang "berbunga-bunga" yang belum tentu dipahami oleh masyarakat golongan tertentu.

Iklan politik merupakan salah satu pemasaran politik untuk mendulang dukungan pemilih. Sebagai pemasaran politik, iklan politik mengikuti logika teori komunikasi publik yang sering disingkat AIDDA, yakni attention, interest, desire, decission, dan action. Tidak mengherankan jika kemudian muncul iklan-iklan politik yang hanya mengobral sensasi, menonjolkan gelar akademis, dan narsis (Jazeri, 2009). Para pengiklan politik di Indonesia, menurut Tinarbuko (2009:31) lebih mengutamakan idologi daripada ideologi. Hal ini dapat ditinjau dari pola-pola seragam yang terdapat dalam iklan politik tersebut seperti angka yang ditulis besar, foto wajah sangat besar, dan janji politik yang juga ditulis dengan font size sangat besar. Para kandidat memosisikan dirinya sebagai produk yang diperjualbelikan. Dengan visualisasi peci, jilbab, gelar akademik, dan aktivitas sosial-keagamaan diyakini mampu mencitrakan sosok caleg, capres, atau calon kepala daerah yang agamis, intelek, dan membela rakyat. Melalui bahasa, para caleg, capres, dan partai politik melempar wacana yang mengagung-agungkan diri dan tak jarang menyerang lawan politik lain. Dengan demikian, akibat yang muncul, yaitu pesan yang disampaikan masih berkisar pada produk, bukan gagasan. Dengan demikian, iklan politik yang muncul sebagian besar hanya sekadar mengenalkan nomor urut, logo partai, atau menonjolkan figur tertentu.

Pada hakikatnya media massa adalah sebuah media komunikasi yang bertujuan menyampaikan informasi. Pada praktiknya, media massa juga menjadi ajang arena pertarungan berbagai kepentingan. Hal itu tampak dari pernyataan Sobur (2006:30) bahwa media merupakan arena pergulatan antarideologi yang saling berkompetisi (the battle ground for competing ideologies). Salah satu segmen yang dipilih di media massa oleh penguasa atau calon penguasa adalah media iklan. Iklan politik ini disebarkan melalui media cetak dan media elektronik. Di atas telah dikemukakan, terdapat perkembangan dalam penggunaan media kampanye, yaitu dengan semakin banyaknya penggunaan media luar ruang. Media luar ruang yang biasa digunakan untuk berkampanye ini di antaranya billboard, baliho, selebaran (leaflet), spanduk, dan poster. Setiap jenis media tersebut memiliki fungsi dan segmen tersendiri.

Dalam contoh media luar ruang untuk kampanye politik, para pengiklan memanfaatkan gaya retorika dengan memilih bentuk tuturan yang memiliki daya tuturan yang diharapkan dapat memengaruhi petutur (Leech, 1983). Kata yang digunakan adalah bentuk perintah atau ajakan, ditandai oleh pilihan kata, seperti pilih, antarkan, mohon, dan pastikan.

62 | Ranah, Volume 3, Nomor 1, Juli 2014 
Berdasarkan latar belakang yang telah dipaparkan, tulisan ini hendak menjawab rumusan masalah berikut; seperti apa bahasa iklan politik pemilu di Indonesia merepresentasikan para kandidat dan partai? Seperti apa relasi antara kandidat dan khlayak dibentuk dalam bahasa iklan politik pemilu di Indonesia? Dengan cara apa bahasa dimanipulasi untuk kepentingan politik di dalam iklan politik pemilu di Indonesia?

\section{Kerangka Teori}

Dalam penelitian ini, digunakan teori representasi yang dikemukakan oleh Leeuwen (2008) untuk menganalisis bagaimana iklan politik pemilu di Indonesia merepresentasikan para caleg dan partai. Di dalam pembahasan ini, akan dilihat bagaimana para caleg dan partai menampilkan diri mereka melalui bahasa di dalam media kampanye yang mereka gunakan. Di dalam penelitian ini juga akan dibahas bagaimana praanggapan muncul di dalam bahasa iklan politik pemilu luar ruang. Terakhir, akan digunakan juga teori pendukung tentang relasi yang dikemukakan Fairclough $(1995 ; 2003)$ untuk menganalisis relasi yang dibangun antara caleg dan audiens dalam bahasa iklan politik Pemilu di Indonesia. Dalam proses analisis representasi dan relasi akan muncul manipulasi bahasa yang digunakan para caleg dan partai politik.

Istilah representasi menunjuk pada bagaimana seseorang, satu kelompok, gagasan atau pendapat tertentu ditampilkan dalam pemberitaan (teks) (Eriyanto, 2003: 113). Hal yang esensi dalam memahami representasi ini adalah apakah seseorang, kelompok, atau gagasan tertentu disampaikan berdasarkan fakta atau tidak. Sebuah peristiwa atau orang dapat disampaikan dengan berbagai macam konstruksi kebahasaan yang akan membangun makna di benak para pembaca. Dengan kata lain, melalui kata, kalimat, aksentuasi, dan bantuan foto, seseorang, kelompok, atau gagasan ditampilkan dalam pemberitaan pada khalayak.

Terpengaruh studi sosiolinguistik Brown dan Gilman (1960), Fairclough (2003:76) menyatakan bahwa relasi sosial terbagi ke dalam dua dimensi, yaitu "kekuasaan atau kekuatan" dan "solidaritas", atau "hierarki sosial" dan "jarak sosial". Relasi berkaitan dengan bagaimana para partisipan berhubungan dan ditampilkan dalam teks. Teks dapat dipandang sebagai arena sosial yang di dalamnya semua kelompok, golongan, dan khalayak yang ada dalam masyarakat saling berhubungan dan menyampaikan versi pendapat dan gagasannya (Eriyanto, 2003: 300). Kajian terhadap relasi di dalam bahasa iklan politik akan melihat bagaimana para pengiklan atau politisi menampilkan pola hubungan dengan masyarakat pemilih. Para politisi dapat menampilkan relasi antara dirinya dengan masyarakat pemilih sebagai relasi yang dekat atau jauh, tinggi-rendah atau setara, kuat-lemah atau sama, satu budaya atau tidak, dan satu ideologi atau tidak.

\section{Data Penelitian}

Data yang digunakan dalam penelitian ini adalah data tulisan yang berupa tuturan dalam iklan politik. Data tersebut dituangkan dalam berbagai bentuk media iklan, seperti baliho, spanduk, leaflet, pamflet, kartu nama, dan iklan di surat kabar atau majalah. Penelitian ini menggunakan enam media iklan berbentuk baliho yang dipergunakan oleh partai Demokrat untuk mempromosikan Susilo Bambang Yudhoyono dan Boediono sebagai kandidat calon presiden dan calon wakil presiden pada tahun 2009. Data kajian terdiri atas 
lima baliho yang memperlihatkan sosok Susilo Bambang Yudhoyono sebagai kandidat calon presiden dan Boediono sebagai kandidat calon wakil presiden secara bersama-sama. Pose yang ditunjukkan hanya terdiri atas dua pose yakni pose close up dan pose setengah badan. Adapun satu baliho yang lain menunjukkan sosok wajah Susilo Bambang Yudhoyono yang ditempelkan pada kemasan mie instan.

Selain itu, keenam data yang dijadikan bahan penelitian ini dipilih berdasarkan beberapa argumentasi, yakni jangkauan keterbacaan publik yang luas, strategi penempatan iklan yang dapat dengan mudah diakses khalayak, memiliki ciri unik dan khas seperti memanfaatkan media yang telah dikenal publik untuk mempromosikan kandidat. Media baliho dipilih sebagai data pengkajian karena menjadi alternatif utama mesin partai dalam media berpolitik. Selain itu baliho dipandang merupakan sarana termudah untuk mempromosikan diri, partai politik, serta visi-misi kandidat kepada masyarakat luas. Media kampanye tersebut juga dapat dengan mudah ditemukan di lingkungan tempat tinggal, jalan-jalan, pusat keramaian, pinggir jalan, terminal, atau lapangan pada saat masa kampanye atau bahkan sebelum kampanye dimulai.

Di dalam iklan tersebut terdapat beberapa jargon yang dipergunakan, yakni Pemerintahan Bersih, Lebih Tepat, Lebih Baik, dan Lebih Ramah, Siap Menang Melanjutkan Pembangunan Rakyat, Nyata Paling Sederhana, dan Buang Korputor Lebih Banyak. Ungkapan-ungkapan inilah yang akan dijadikan sebagai salah satu bahan analisis.

\section{Metode Penelitian}

Di dalam penelitian ini metodologi yang dipergunakan adalah metode deskriptif kualitatif. Pembahasan pertama yang menjadi objek kajian adalah unsur bahasa yang terdapat di dalam media kampanye. Pada bagian ini ditelisik keberadaan unsur bahasa dipergunakan, dimanipulasi, dan dikonstruksi oleh para kandidat dan partai dalam upaya menampilkan diri pada media kampanye yang mereka gunakan. Di dalam penelitian ini juga akan dibahas bagaimana praanggapan muncul di dalam bahasa iklan politik pemilu luar ruang. Untuk mendukung pengkajian dipergunakan teori tentang relasi yang dikemukakan Fairclough (1995; 2003). Hal ini bertujuan untuk menganalisis relasi yang dibangun antara caleg dan audiens dalam bahasa iklan politik Pemilu di Indonesia. Pada akhirnya, akan diperoleh kesimpulan proses representasi dan relasi akan muncul manipulasi bahasa yang digunakan para caleg dan partai politik.

\section{Representasi Calon Presiden dan Calon Wakil Presiden dalam Iklan Pemilu tahun 2009}

Bahasa di dalam konteks politik dapat menjadi alat kuasa atau kekuatan simbolik. kekuatan simbolik adalah sebuah kekuatan tak tampak-dan bersifat distorsif-tetapi diakui secara legitimasi. Sebuah bahasa dianggap legitimate atau illegitimate sangat bergantung pada siapa yang mengucapkannya (Piliang, 2005: 203). Bahasa digunakan sebagai alat untuk membangun penopengan atau manipulasi citra. Bahasa memiliki kekuatan untuk membangun citra seorang politisi atau partai politik. Terjadi permainan bebas tanda dan citra sebagaimana dikatakan Piliang (2005). Fenomena permainan bebas tanda dan citra, tanpa perlu mengikatkan diri pada satu determinasi (metafisik) tertentu yang tampaknya telah menjadi lukisan dunia politik masa kini. Tanda dan citra politik kini tidak lagi 
dibicarakan dalam konteks kebenaran dan kepercayaan yang ditawarkannya, melainkan permainan murni, dalam rangka mencapai kekuasaan murni, yaitu kekuasaan yang tidak lagi mempunyai tanggung jawab sosial (Piliang, 2005: 16).

Dengan demikian, bahasa politik sangat erat kaitannya dengan upaya untuk merebut simpati rakyat. Bahasa politik hadir dan dibutuhkan untuk menumbuhkan pencitraan tertentu agar rakyat terpengaruh dan tersugesti oleh propaganda dan ikon-ikon politik yang mereka tawarkan. Salah satu fungsi bahasa adalah merepresentasikan realitas. Bahasa tidak hanya berfungsi menyampaikan informasi, tetapi juga menampilkan bagaimana realitas yang direpresentasikan. Istilah representasi menunjuk pada bagaimana seseorang, satu kelompok, gagasan atau pendapat tertentu ditampilkan dalam pemberitaan (teks) (Eriyanto, 2003: 113). Hal yang esensi dalam memahami representasi ini adalah apakah seseorang, kelompok, atau gagasan tertentu disampaikan berdasarkan fakta atau tidak. Sebuah peristiwa atau orang dapat disampaikan dengan berbagai macam konstruksi kebahasaan yang akan membangun makna di benak para pembaca. Dengan kata lain, melalui kata, kalimat, aksentuasi, dan bantuan foto, seseorang, kelompok, atau gagasan ditampilkan dalam pemberitaan pada khalayak.

Partai Demokrat didirikan pada 9 September 2001 dan disahkan pada 27 Agustus 2003. Partai ini didirikan Susilo Bambang Yudhoyono, yang kala itu menjadi Menteri Koordinator bidang Politik dan Keamanan di bawah Presiden Megawati. Susilo Bambang Yudhoyono

Data PD 1-3

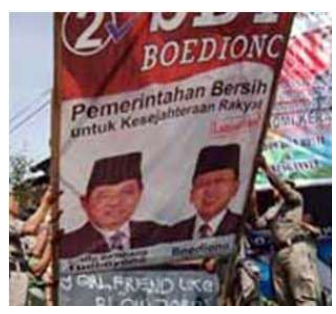

Data PD 3-7

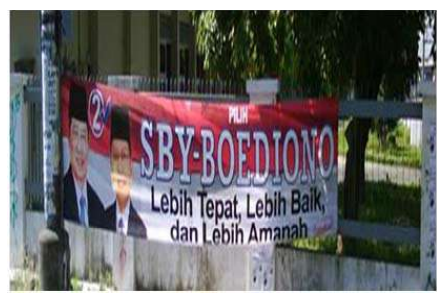

Data PD 5-27

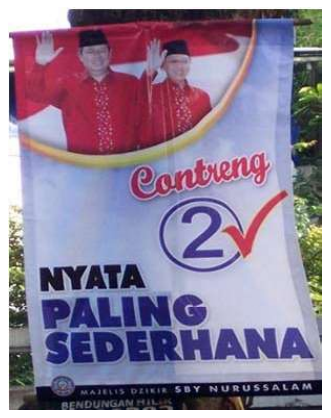

Data PD 2-6

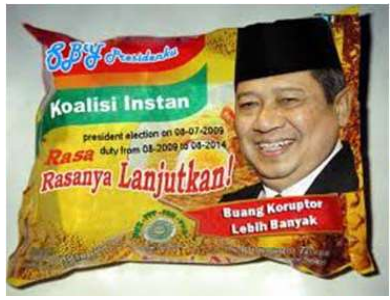

Data PD 4-10

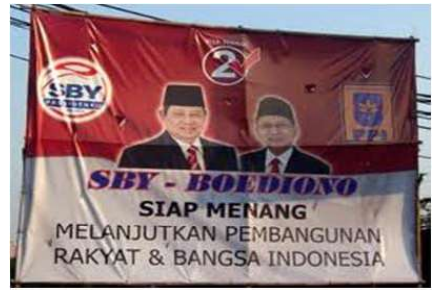

Data 6-28

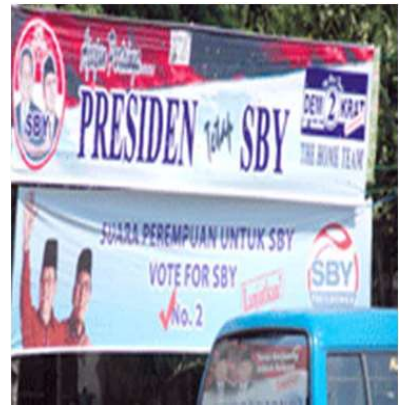


berpasangan dengan Jusuf Kalla memenangkan Pemilu tahun 2004 dan berkuasa hingga 2009. Pada Pemilu 2009, SBY berpasangan denga Boediono yang sebelumnya menjabat sebagai Deputi Gubernur Bank Indonesia.

Berikut akan ditampilkan data media kampanye yang dilakukan oleh kedua kandidat dalam media baliho ketika kampanye Pemilu tahun 2009 dilaksanakan:

Representasi calon presiden (capres) dan calon wakil presiden (cawapres) terdapat pada data PD 1-3, PD 2-6, PD 3-7, PD 4-10, PD 5-27, PD 6-28. Data PD 1-3 memiliki tuturan "SBY BOEDIONO Pemerintahan Bersih Untuk kesejahteraan Rakyat, Lanjutkan!", data PD 2-6 memiliki tuturan "SBY Presidenku", Rasanya Lanjutkan!", dan "Buang Koruptor Lebih Banyak", data PD 3-7 memiliki tuturan "SBY-BOEDIONO Lebih Tepat, Lebih Baik, dan Lebih Amanah", data PD 4-10 memiliki tuturan "SBY PRESIDENKU, SBY-BOEDIONO SIAP MENANG MELANJUTKAN PEMBANGUNAN RAKYAT \& BANGSA INDONESIA", data PD 5-27 memiliki tuturan "NYATA PALING SEDERHANA", dan data PD 6-28 memiliki tuturan "Presiden tetap $S B Y$ " dan "Suara Perempuan untuk SBY Vote for SBY No 2".

Secara umum, data-data iklan ini merepresentasikan capres dan cawapres sebagai sosok yang bersih, berjuang untuk rakyat, merupakan presiden pilihan, berkomitmen untuk membangun pemerintahan bersih, dan berkomitmen untuk membangun rakyat Indonesia. Secara visual, umumnya data-data ini menampilkan SBY-Boediono dengan pakaian merah dengan latar belakang bendera merah putih (Bendera Indonesia) atau bendera partai Demokrat.

Data PD 1-3 "SBY BOEDIONO Pemerintahan Bersih Untuk kesejahteraan Rakyat, Lanjutkan!" merepresentasikan bahwa SBY-Boediono merupakan pasangan yang memiliki komitmen untuk menyelenggarakan pemerintahan yang bersih. Pemerintahan bersih (Good governance) adalah istilah yang digunakan untuk menggambarkan bagaimana institusi publik melakukan urusan publik dan mengelola sumber daya publik dengan baik. Pemerintahan adalah "proses pengambilan keputusan dan proses pengimplementasian sebuah keputusan." Pada data ini, SBY-Boediono direpresentasikan sebagai pasangan capres dan cawapres yang berkomitmen di dalam menyelenggarakan pemerintahan yang terbebas dari korupsi, kolusi, dan nepotisme. Dengan demikian, pemerintahan ini dapat mengelola urusan publik dan sumber daya dengan baik. Ungkapan yang terdapat dalam iklan tersebut merupakan salah satu bentuk persuasife kepada publik untuk menciptakan sebuah perbedaan antara pemerintahan yang digawangi SBY dengan pemerintahan sebelumnya. Iklan ini mencitrakan bahwa pemerintahan SBY merupakan pemerintahan yang bersih dan berkomitmen dengan pemberantasan korupsi.

Dengan demikian, di dalam iklan ini secara tidak langsung menunjukkan sebuah oposisi biner mengenai ide pemerintahan. Melalui iklan ini pemerintahan SBY diandaikan merupakan satu-satunya pemerintahan yang terbebas dari jerat korupsi jika diperbandingkan dengan pemerintahan sebelumnya. Iklan ini cenderung ingin memberikan harapan kepada masyarakat tentang tata kelola pemerintahan yang selama ini dibayangkan.

Sementara itu, data PD 2-6 "SBY Presidenku", "Rasanya Lanjutkan!", dan "Buang Koruptor Lebih Banyak" memiliki kaitan dengan representasi pada data PD 1-3. Di dalam data tersebut, SBY direpresentasikan sebagai presiden pilihan rakyat. Hal ini ditunjukkan dengan penggunaan $-k u$ di dalam presidenku. Kata $-k u$ di dalam tuturan ini merepresentasikan rakyat. Ada peminjaman atau "perampokan" bahasa (language robbery). Aku yang merujuk pada rakyat digunakan untuk melegitimasi bahwa SBY adalah presiden pilihan semua rakyat. 
Oleh sebab itu, hal ini menjadi landasan bagi partai Demokrat untuk menyatakan bahwa pemerintahan SBY harus dilanjutkan. Hal ini direpresentasikan oleh tuturan "Rasanya Lanjutkan!". Sementara itu, tuturan "Buang Koruptor Lebih Banyak" memiliki kaitan erat dengan data PD 3. SBY direpresentasikan sebagai presiden yang berkomitmen di dalam pemberantasan korupsi. Pemberantasan korupsi ini dilakukan untuk menyelenggarakan pemerintahan yang bersih sebagaimana direpresentasikan pada data PD 3.

Menarik untuk membandingkan antara iklan PD 2-6 dengan iklan PD 3. Kedua-duanya menyimbolkan bahwa pemerintahan yang digawangi oleh SBY sungguh berkomitmen terhadap pemberantasan korupsi. Tema pemberantasan korupsi menjadi pokok utama representasi pemerintahan SBY dalam menciptakan diferensiasi citra dengan kandidat yang lain, seperti pasangan Jusuf Kalla-Wiranto yang cenderung menciptakan citra sebagai pemerintahan yang responsif. Walaupun begitu, saya kira pemilihan citra sebagai pemerintahan yang berkomitmen dalam pemberantasan korupsi ini justru memberikan lebih banyak keuntungan pada pihak SBY-Boediono. Hal ini dikarenakan pada periode tersebut masyarakat sedang mengalami euforia keinginan pemberantasan korupsi yang sedemikian masif. Secara tidak langsung pola penerapan iklan yang seperti ini telah berhasil masuk ke dalam impian bawah sadar masyarakat pada umumnya. Dari hal ini terdapat sebuah kecocokan antara harapan rakyat akan pemberantasan korupsi dengan iklan yang ditampilkan oleh SBY-Boediono. Momentum inilah yang penulis argumentasikan mengapa pada pemilu tahun 2009 pasangan SBY-Boediono meraih raupan suara yang tinggi dibandingkan peserta lain.

Data PD 3-7 memiliki tuturan "SBY-BOEDIONO Lebih Tepat, Lebih Baik, dan Lebih Amanah" merepresentasikan SBY-Boediono sebagai pasangan capres dan cawapres yang baik dan ideal. Di dalam kebudayaan Indonesia, mayoritas penduduknya beragama Islam, pemimpin yang baik adalah pemimpin yang tepat, memiliki sikap baik dan amanah. Hal ini direpresentasikan di dalam frasa "Lebih Tepat", "Lebih Baik", dan "Lebih Amanah". Hal ini juga merepresentasikan adanya capres dan cawapres lain. Akan tetapi, capres dan cawapres lain tidak tepat, buruk, dan tidak amanah. Oleh sebab itu, SBY dan Boediono dianggap dan direpresentasikan sebagai pemimpin yang ideal untuk memimpin Indonesia pada periode 2009-2014. Dari data PD 3-7 tersirat bahwa kandidat SBY-Boediono melalui iklan yang ditampilkan menciptakan sebuah diferensiasi dengan kandidat lain. Oposisi biner yang dibangun tentu saja menghasilkan nilai positif bagi pasangan SBY-Boediono. Jika pasangan Jusuf Kalla-Wiranto memiliki jargon "Lebih Cepat-Lebih Baik", hal tersebut tidaklah cukup dapat memenuhi tuntutan untuk mencapai tata kelola pemerintahan yang baik.

Iklan SBY-Boediono justru mengambil ide dari pasangan Jusuf Kalla-Wiranto untuk membangun citra yang lebih unggul dari mereka melalui ungkapan "Lebih Tepat", "Lebih Baik", dan "Lebih Amanah." Kata "Tepat" merupakan variasi lain dari "Cepat." Namun demikian, kata "Tepat" memiliki konotasi yang lebih positif dibandingkan ungkapan "Cepat." Kata "Tepat" ini seolah menegaskan bahwa kecepatan bukanlah hal yang dapat dijadikan tolok ukur dalam mengelola pemerintahan tetapi ketepatanlah yang lebih banyak dipergunakan. Hal ini diperkuat dengan penambahan kata "Amanah" setelah kata "Baik" yang tidak ditemukan pada jargon pasangan kandidat Jusuf Kalla-Wiranto. Jargon "Amanah" memiliki dua fungsi positif sekaligus kepada pasangan SBY-Boediono. Selain ini kembali menguatkan mitos pemerintahan yang bersih dan terbebas dari korupsi, jargon ini juga secara tidak langsung memberikan pengaruh negatif kepada pasangan Jusuf Kalla-Wiranto. Kesan yang timbul pasangan ini baru sampai tahap "berbuat baik" tetapi "belum amanah." 
Artinya pasangan kandidat Jusuf Kalla-Wiranto dicitrakan jika kelak keduanya berkuasa perilaku korupsi masih akan terus terjadi sebab keduanya baru sampai pada posisi baik semata, belum amanah.

Data PD 4-10 memiliki tuturan "SBY PRESIDENKU, SBY-BOEDIONO SIAP MENANG MELANJUTKAN PEMBANGUNAN RAKYAT \& BANGSA INDONESIA". Data ini merepresentasikan SBY-Boediono sebagai presiden yang siap menang dan melanjutkan program pembangunan. Hal ini karena Susilo Bambang Yudhoyono adalah calon presiden incumbent. Dia adalah calon presiden yang pada saat itu masih menjabat sebagai Presiden Republik Indonesia. Misi pencalonan SBY-Boediono adalah untuk melanjutkan program pembangunan rakyat dan bangsa Indonesia yang telah dilaksanakan oleh Presiden SBY pada periode pertama 20042009. Pemilihan frasa "rakyat dan bangsa Indonesia" di dalam iklan ini merepresentasikan bahwa yang akan dibangun oleh pasangan ini bukan hanya persoalan fisik. Akan tetapi, persoalan-persoalan yang bersifat mental, jati diri, sikap, dan budaya.

Data PD 5-27 memiliki tuturan "NYATA PALING SEDERHANA" merepresentasikan pasangan SBY-Boediono sebagai pasangan yang "nyata". Di dalam KBBI, nyata berarti terang (kelihatan dan kedengaran); jelas sekali; kentara. Dengan demikian, pasanganpasangan capres-cawapres lain dianggap sebagai tidak nyata atau tidak jelas keberadaan dan komitmennya untuk menjadi presiden dan wakil presiden Republik Indonesia. Selain itu, frasa "PALING SEDERHANA" merepresentasikan pasangan ini sebagai pasangan yang bersahaja dan tidak berlebih-lebihan. Hal ini mengindikasikan pasangan lain sebagai pasangan yang tidak bersahaja dan berlebih-lebihan.

Ungkapan "NYATA PALING SEDERHANA" dapat dipandang sebagai bentuk antitesa pasangan SBY-Boediono dengan kedua pasangan kandidat calon presiden lain. Sebagaimana diketahui, kedua pasangan kandidat yang menjadi lawan SBY-Boediono merupakan para pengusaha sukses yang memiliki kekayaan yang cukup signifikan. Ungkapan ini secara tidak langsung dapat dipahami sebagai bentuk perlawanan terhadap sosok Jusuf Kalla dan Prabowo Subianto yang digadang-gadang memiliki kekayaan luar biasa.

Nilai-nilai yang bertolak belakang ini melahirkan sebuah oposisi yang menguntungkan SBY-Boediono. Dalam alam pikiran bawah sadar masyarakat Indonesia, berlimpahnya kekayaan seringkali diasosiasikan dengan kehidupan foya-foya dan rakus. Hal ini tentu memberikan kesan bahwa kedua pasangan lain cenderung berorientasi pada pengejaran kekayaan alias keduniawian. Berbeda dengan pasangan SBY-Boediono yang disebut sebagai sosok "NYATA PALING SEDERHANA". Ungkapan ini mengonstruksikan sebuah mitos citra bahwa pemerintahan SBY-Boediono tidaklah berorientasi kepada pengumpulan kekayaan tetapi berperilaku zuhud atau menghindari nilai-nilai keduniawian. Selain itu, ungkapan "NYATA PALING SEDERHANA" juga memberikan sebuah asosiasi kedekatan SBY-Boediono dengan citra rakyat kebanyakan yang diasumsikan memiliki kehidupan yang sederhana. Dari hal tersebut penulis berargumentasi bahwa pemilihan kata "NYATA PALING SEDERHANA" diperuntukan demi meraih simpati publik yang berasal dari golongan menengah ke bawah. Hal ini akan berbeda dengan data iklan sebelumnya yang cenderung berusaha untuk meraih simpati pemilih yang berasal dari kelas menengah hingga atas.

Data PD 6-28 memiliki tuturan "Presiden tetap SBY" dan "Suara Perempuan untuk SBY Vote for SBY No 2". Data ini merepresentrasikan pilihan yang dilakukan rakyat yaitu bahwa rakyat tetap memilih SBY sebagai presiden di pemerintahan yang akan datang. Selain itu, perempuan juga memilih SBY sebagai presiden. Hal ini mengindikasikan ada golongan 
gender tertentu yang direpresentasikan secara menyeluruh memilih SBY sebagai presiden. Pada data iklan PD 6-28 ini pasangan SBY-Boediono memainkan politik gender untuk meraih simpati publik, khususnya kaum perempuan. Jika iklan pasangan kandidat lain cenderung memiliki sifat maskulin dalam merepresentasikan dirinya, pasangan SBY-Boediono justru mencoba mencitrakan diri bahwa keduanya juga dekat dengan nilai-nilai feminin. Hal ini dilakukan bukan tanpa alasan. Ibu yang identik dengan nilai-nilai feminine merupakan sosok yang dijunjung tinggi oleh masyarakat Indonesia. Pemilihan ungkapan "Suara Perempuan untuk SBY Vote for SBY No 2". Menimbulkan dua persepsi ke tengah masyarakat. Kalimat "Suara Perempuan untuk SBY" beresonansi atau memiliki persamaan makna dengan "Suara Ibu Pertiwi Untuk SBY" yang pada akhirnya menimbulkan makna jika sosok SBY benarbenar direstui untuk memimpin tata kelola pemerintahan. Hal itu tentu saja dipandang harus didukung oleh segenap lapisan masyarakat sebab dalam kalimat "Suara Perempuan untuk SBY" yang secara aktif memberikan dukungan adalah kaum perempuan yang dapat dimaknai bahwa ibu pertiwi memberikan restunya kepada SBY. Dua keuntungan diperoleh melalui pemakaian iklan ini. Selain mampu menjangkau pemilih perempuan, para pemilih laki-laki pun didesak untuk meilih pasangan SBY-Boediono. Manipulasi kata inilah yang menjadi senjata utama pasangan SBY-Boediono untuk meraih dukungan signifikan pada pemilu tahun 2009 dibandingkan pasangan kandidat lain.

\section{Simpulan}

Iklan politik merupakan salah satu pemasaran politik untuk mendulang dukungan pemilih. Tidak mengherankan jika kemudian muncul iklan-iklan politik yang hanya mengobral sensasi, menonjolkan gelar akademis, dan cenderung narsis. Para pengiklan politik di Indonesia lebih mengedepankan angka yang ditulis besar, foto wajah sangat besar, dan janji politik yang juga ditulis dengan font size sangat besar. Mereka memosisikan dirinya sebagai produk yang diperjualbelikan. Dengan visualisasi peci, jilbab, gelar akademik, dan aktivitas sosial-keagamaan diyakini mampu mencitrakan sosok caleg, capres, atau calon kepala daerah yang agamis, intelek, dan membela rakyat. Melalui bahasa, para pengiklan melempar wacana yang mengagung-agungkan dirinya dan tak jarang menyerang lawan politiknya. Pesan yang disampaikan masih berkisar pada produk, bukan gagasan.

Dalam penelitian ini, data yang merepresentasikan calon presiden (capres) dan calon wakil presiden (cawapres) terdapat pada data PD 1-3, PD 2-6, PD 3-7, PD 4-10, PD 5-27, PD 6-28. Data yang diperoleh merepresentasikan pemerintahan yang bersih yang ditegaskan dengan frasa "Buang koruptor lebih banyak", mengajak masyarakat untuk melanjutkan pemerintahan dengan capres dan cawapres yang lebih baik, lebih amanah, dan lebih 
tepat. Capres-cawapres yang direpresentasikan sebagai calon yang sederhana, bersih, berkomitmen untuk melanjutkan pemerintahan demi kesejahteraan rakyat. Pemilihan frasa "rakyat dan bangsa Indonesia" di dalam iklan ini merepresentasikan bahwa yang akan dibangun oleh pasangan ini bukan hanya persoalan fisik. Akan tetapi, persoalan-persoalan yang bersifat mental, jati diri, sikap, dan budaya. Terdapat pula data yang mengajak perempuan untuk memilih SBY sebagai presiden.

\section{Daftar Pustaka}

Eriyanto. 2003. Analisis Wacana. Yogyakarta : Pustaka Pelajar.

--------. 2006. Analisis Wacana Pengantar analisis teks media. Yogyakarta : LKiS Pelangi Aksara.

Fairclough, N. 1995. Critical Discourse Analysis: The Critical Study of Language. Harlow-Essex: Longman Group Limited.

--------. 2003. Analysing Discourse Textual Analysis for Social Research. London \& New York: Routledge.

Jazeri. 2009. "Menabur Bahasa, Menuai Kuasa (Memahami Relasi Bahasa dan Kekuasaan dalam Iklan Politik)". www.Jeyrenggono.com (diunduh 14 Oktober 2011).

Leeuwen . 2008. Discourse and Practice New Tool for Critical Discourse Analysis. New York: Oxford University Press.

Piliang, Yasraf Amir. 2005. Transpolitika Dinamika Politik di dalam Era Virtualitas. Yogyakarta : Jalasutra.

Sobur, Alex. 2006. Analisis Teks Media Suatu Pengantar untuk Analisis Wacana, Analisis Semiotik, dan Analisis Framing. Bandung : Remaja Rosdakarya.

Sulistyaningtyas, Tri. 2014. "Representation of Legislative Member Candidates of Partai Demokrat on Their Outdoor Political Advertising" dalam International Journal of Linguistics, Vol. 6, No. 2, April 2014, Canada.

Tinarbuko, Sumbo. 2009. Iklan Politik dalam Realitas Media. Yogyakarta : Jalasutra. 
